\title{
Penggunaan Minyak Zaitun Ekstra Virgin ke dalam Bahan Pengencer Semen terhadap Kualitas Spermatozoa Ayam Lokal
}

\author{
The Use of Extract Virgin Olive Oil to Semen Extender on Local Chicken \\ Spermatozoa Quality
}

\author{
Khaeruddin $^{1}$, C. Sumantri ${ }^{1}$, S. Darwati ${ }^{1}$, R.I. Arifiantini ${ }^{2}$ \\ ${ }^{1}$ Departemen Ilmu Produksi dan Teknologi Peternakan, Fakultas Peternakan, Institut Pertanian Bogor \\ ${ }^{2}$ Departemen Klinik, Reproduksi dan Patologi, Institut Pertanian Bogor \\ ${ }^{\#} J l n$. Agatis Kampus IPB Dramaga, Bogor 16680 \\ Correspondence author : erukhaeruddin@gmail.com
}

\begin{abstract}
The aim ofthis study was to examine the preservability of local chicken semen in extender added with various level extra virgin olive oil (EVOO).Semen was collected from three roosters using massage method. Immediately after collection the semen evaluated macro and microscopically. Semen demonstrated $>\mathbf{7 0} \%$ motility, individually divided into five tubes. Each of them diluted with ringer fructose that supplemented with $0 \%, 4 \%, 6 \%, 8 \%$ or $10 \%$ EVOO. Semen was stored in refrigerator $\left(5{ }^{\circ} \mathrm{C}\right)$ for sixty hours and evaluated every twelve hours for spermatozoa motility and viability. Results revealed that supplementing the diluent of roosters semen with EVOO and then storing it for different storage periods $(12,24,36,48$ or 60 hours) resulted in significant $(p<0.05)$ improvement in spermatozoa motility and viabilityin comparison with the control group.Moreover, used of $8 \%$ EVOO surpassed other treatments afterin vitro storage for up to 60 hoursand resulted fertilizing ability up to $73.81 \%$.This research conclude that $8 \%$ EVOO can be used as antioxidant source for roosters semen during preservation.
\end{abstract}

Keywords : extender, local chicken, extract virgin olive oil, spermatozoa,

\section{PENDAHULUAN}

Inseminasi buatan (IB) merupakan suatu paket teknologi yang diharapkan dapatmeningkatkan produktivitas ayam lokal yang ada di Indonesia. IB pada ayam merupakan gabungan dari beberapa teknologi, yaitu teknologi penampungansemen, teknologipengenceran danpenanganan semen serta teknologi pembuahan dan keberhasilannya. Pada proses pengenceran diperlukan adanya suatu upaya untuk mempertahankan kualitas spermatozoa ayam selama penyimpanan yaitu dengan penambahan zat-zat tertentu yang dapat menjamin kebutuhan fisik dan kimia bagi spermatozoa.

Penyimpanan semen menyebabkan spermatozoa rentan mengalami serangan radikal bebas (oksidan) yang dapat menyebabkan kerusakan pada sel. Radikal bebas dapat berasal dari produk samping rantai respirasi di dalam mitokondria. Pada proses respirasi, oksigen mengalami reduksi dalam rangkaian transpor elektronyang menghasilkan radikal bebas(Siregar, 1992). Radikal bebas sangat reaktif dan dapat bereaksi dengan asam lemak tak jenuh. Membran plasma spermatozoa kaya akan asam lemak tak jenuh sehingga rentan terhadap kerusakan yang disebabkan peroksidasi lipid (Blesbois et al.,1997). Peroksidasi lipid yang berkepanjangan merusak struktur matrik lipid dan menyebabkan instabilitas pada membran. Peningkatan kerusakan pada sistem non membran juga dapat terjadi. Karena spermatozoa tidak dapat melakukan biosintesis untuk memperbaiki kerusakan, maka dapat menyebabkan perubahan pada fungsi spermatozoa (Feradis, 2010). Peroksidasi lipid dapat diatasi dengan cara membran sel spermatozoa harus dilindungi oleh antioksidan yang efektif mencegah kerusakan peroksidatif. Aktifitas beberapa antioksidan alami (katalase dan superoksida dismutase) pada semen berkurang selama penyimpanan. Aktivitas enzim katalase pada semen ayam berkurang setelah kriopreservasi hingga 14\% demikian juga dengan aktifitas superoksida dismutase (Partyka et al.,2012). Hal ini menandakan bahwa antioksidan alami pada semen ayam tidak sepenuhnya mencegah efek negatif dari peroksidasi lipid yang terjadi selama penyimpanan semen, untuk mengatasi hal tersebut diperlukan penambahan antioksidan dari luar yang mampu menghambat peroksidasi lipid selama penyimpanan. Spermatozoa unggas memiliki konsentrasi asam lemak tak jenuh ganda (PUFA) yang tinggi selama penyimpanan in vitro, seperti pada spermatozoa ayam, kalkun, angsa, bebek dan guinea fowl kaya akan asam lemak arakidonat (20:4n-6) dan asam lemak dokosatetranoeat (22:4n-6), namun spermatozoa ayam memiliki kadar asam lemak dokosatetranoeat lebih tinggi dari yang lain (Surai et al.,2001) sehingga spermatozoa ayam lebih rentan terhadap peroksidasi lipid. Hal ini didukung oleh pendapat Cerolini et al. (2006) bahwa membran sel spermatozoa ayam banyak mengandung asam lemak tak jenuh ganda yang mudah mengalami peroksidasi lipid. Peroksidasi lipid menyebabkan beberapa 
kerusakan pada spermatozoa unggas, berupa kerusakan morfologis, penurunan motilitas, dan daya fertil (Long dan Kramer, 2003), sehingga spermatozoa ayam yang disimpan memerlukan senyawa antioksidan seperti minyak zaitun. Minyak zaitun menjadi salah satu antioksidan eksogen yang memiliki banyak manfaat. Pada minyak zaitun terdapat gugus phenol, terdiri dari struktur cincin aromatik dengan satu atau lebih gugus hidroksil. Semakin banyak gugus hidroksil yang terkandung dalam gugus phenol menunjukkan kemampuan antioksidan yang lebih baik(Vissers et al.,2004). Salah satu jenis minyak zaitun yang sering dikonsumsi adalah minyak zaitun ekstra virgin. Minyak ini berasal dari buah zaitun hasil proses tahap pertama sehingga tidak banyak kandungan gizi yang hilang serta mengandung sejumlah polifenol dengan kadar yang lebih tinggi dari minyak zaitun yang telah beberapa kali diproses (revined olive oil) (Vossen, 2007) dengan kandungan paling sedikit dua gugus hidroksil(Vissers et al.,2004).

Penelitian mengenai pemanfaatan antioksidan pada pengencer semen seperti vitamin E telah banyak dilaporkan sebelumnya pada unggas (Tabatabaei et al.,2011; Suharyati, 2006; Long dan Kramer, 2003; Al-Daraji, 2000). Namun,penelitian mengenai efek antioksidan minyak zaitun adalah hal yang baru untuk dikaji lebih lanjut keefektifannya sebagai antioksidan pada spermatozoa khususnya pada semen ayam lokal di Indonesia. Penelitian ini bertujuan untuk mencari level minyak zaitun ekstra virgin terbaik dalam pengencer semen ringer laktat kuning telur fruktosa yang dapat mempertahankan kualitas spermatozoa ayam lokal selama penyimpanan. Hasil penelitian ini diharapkan dapat digunakan dalam pengembangan teknologi IB pada ayam di Indonesia.

\section{MATERI DAN METODE}

\section{Waktu dan Tempat Penelitian}

Penelitian ini dilaksanakan pada bulan Mei 2014 sampai dengan bulan September 2014 di Laboratorium Lapangan Fakultas Peternakan IPB dan Laboratorium Unit Rehabilitasi Reproduksi, Fakultas Kedokteran Hewan, Institut Pertanian Bogor.

\section{Materi Penelitian}

Sumber semen berasal dari ayam lokal berumur 1 tahun. Ayam ditempatkan pada kandang individu berukuran $40 \times 50 \times 70 \mathrm{~cm}$ dan diberi pakan komplit berupa crumble untuk ayam petelur sebanyak $150 \mathrm{~g}$ ekor $^{-1}$ hari $^{-1}$ dengan kandungan protein kasar $17 \%$, energi metabolisme $2229.40 \mathrm{Kkal}$, serat kasar 6\%, abu 14\%, fosfor $0.6 \%-1 \%$ dan air minum diberikan ad libitum.

\section{Penyiapan Pengencer}

\section{Prosedur Penelitian}

Bahan pengencer menggunakan buffer ringer laktat (PT Widatra Bhakti) dan kuning telur 10\% (RLKT). Ringer laktat kuning telur dihomogenkan menggunakan stirer selama 5 menit kemudian disentrifugasi selama 10 menit dengan kecepatan $3000 \mathrm{rpm}$. Supernatan digunakan sebagai pengencer dasar dan di-ajust dengan tris (tris hydroxymethyl aminomethane) untuk mendapatkan $\mathrm{pH} 6.8$. Bahan pengencer ditambahkan berbagai level minyak zaitun ekstra virgin (MZEV) (Burcino, Turki) yang disajikan pada Tabel 1.

\section{Koleksi dan Evaluasi Semen}

Koleksi semen menggunakan metode pemijatan sebanyak 3 kali seminggu. Semen yang telah dikoleksi, dievaluasi di laboratorium secara mikroskopis.Pemeriksaan mikroskopis meliputi: (1) motilitas spermatozoa, menggunakan penambahan $\mathrm{NaCl}$ fisiologis, diamati menggunakan mikroskop cahaya dengan pembesaran 10 x 40. Persentase motilitas dinilai secara subyektif dengan membandingkan spermatozoa hidup bergerak ke depan (progresif) dengan yang tidak progresif. Penilaian yang diberikan dari angka $0 \%$ (mati semua) hingga 100\% (motil semua). (2) persentase spermatozoa hidup dilakukan dengan menggunakan pewarna eosin-negrosin, selanjutnya, pemeriksaan di bawah mikroskop cahaya dengan pembesaran $10 \times 40$, terhadap 10 lapang pandang. (3) konsentrasi spermatozoa menggunakan counting chamber dan larutan formol saline. Semen yang menunjukkan motilitas spermatozoa lebih dari 70\% dengan konsentrasi spermatozoa minimal $2500 \times 10^{6}$ digunakan pada penelitian ini.

\section{Pengolahan, Penyimpanan dan Pengamatan Semen} Cair

Semen dibagi ke dalam 5 tabung, masing-masing diencerkan menggunakan pengencer P0, P1, P2, P3 atau P4. Semen cair selanjutnya disimpan dalam refrigerator $\left(5^{\circ} \mathrm{C}\right)$. Pengamatan kualitas semen cair secara in vitro dilakukan terhadap motilitas dan viabilitas spermatozoa pada jam ke-0, 12, 24, 36, 48 dan jam ke-60.

\section{Inseminasi Buatan}

Semen yang telah dikoleksi kemudian diencerkan dengan komposisi pengencer pada uji in vitrosebelum diinseminasi. Inseminasi buatan dilakukan dengan menggunakan metode intra uterine menggunakan spoit $1 \mathrm{~mL}$ dan kateter. Ayam ras petelur yang sedang berproduksi sebagai reseptor IB

Tabel 1. Komposisi bahan pengencer dengan berbagai level minyak zaitun ekstra virgin (MZEV)

\begin{tabular}{llllll}
\hline Unsur pokok & P0 & P1 & P2 & P3 & P4 \\
\hline Minyak zaitun ekstra virgin (mL) & & 0.4 & 0.6 & 0.8 & 1 \\
Fruktosa (g) & 0.201 & 0.201 & 0.201 & 0.201 & 0.201 \\
Penisillin (IU mL-1) & 1000 & 1000 & 1000 & 1000 & 1000 \\
Streptomisin (mg mL-1) & 1 & 1 & 1 & 1 & 1 \\
Buffer (mL)ad & 10 & 10 & 10 & 10 & 10 \\
Tekanan osmotik (mOsmolkg-1) & 339 & 349 & 359 & 373 & 340 \\
\hline
\end{tabular}

Keterangan : P0 =Pengencer RLKTF (ringer laktat kuning telur fruktosa) tanpa minyak zaitun, P1-P4 = pengencer RLKTF yang disuplementasi masing-masing 4\%,6\%,8\% dan $10 \%$ minyak zaitun ekstra virgin. 
sebanyak 3 ekor sebagai ulangan.

\section{Koleksi dan Penetasan Telur}

Telur tetas hasil IB dikoleksi sampai hari ke-7. Telur hari pertama (1 hari setelah IB) dianggap telur infertil sedangkan telur hari kedua sampai dengan hari ke-7 dimasukkan ke dalam mesin tetas. Temperatur mesin tetas $100^{\circ} \mathrm{F}\left(37.8^{\circ} \mathrm{C}\right)$ dengan kelembaban relatif $75 \%$ hingga $80 \%$.Telur diamati menggunakan candler untuk melihat fertilitas. Pemeriksaan fertilitas telur dilakukan pada hari keenam masa penetasan dengan melihat adanya perkembangan embrio dini yang ditandai adanya perkembangan pembuluh darah. Fertilitas telur dinyatakan dalam bentuk jumlah telur fertil, yaitu jumlah telur IB yang berhasil dibuahi oleh spermatozoa yang dihitung dengan rumus:

$$
\text { Fertilitas telur (\%) }=\frac{\text { Jumlah telur fertil }}{\text { Jumlah telur tetas IB }} \times 100 \%
$$

Periode fertil spermatozoa adalah lamanya spermatozoa dalam saluran reproduksi betina dan masih mampu untuk membuahi ovum. Parameter ini dihitung mulai hari ke-2 setelah inseminasi sampai dengan telur tidak menghasilkan tunas, diamati dalam periode 17 hari.

\section{Rancangan Penelitian}

Penelitian ini menggunakan rancangan acak lengkap (RAL)yang terdiri dari 5 perlakuan pengencer (P0, P1, P2, P3, dan P4) dengan 12 kali ulangan. Model rancangan yang digunakan yaitu:

$$
Y_{i j}=\mu+\alpha_{i}+\varepsilon_{i j}
$$

$\mathrm{Y}_{\mathrm{ij}}=$ nilai pengamatan penggunaan MZEV pada taraf ke-i dan ulangan ke-j

$\mu=$ nilai rataan umum

$\alpha_{i}=$ pengaruh penggunaan MZEV pada taraf ke-i

$\varepsilon_{\mathrm{ij}}=$ galat percobaan untuk taraf ke-i dan ulangan ke-j

Data dianalisis menggunakan Analisis of Variance (Anova), selanjutnya apabila ditemukan perbedaan antar perlakuan maka dilanjutkan dengan uji Duncan (Steel dan Torrie 1994).

\section{HASIL DAN PEMBAHASAN}

\section{Kualitas Semen Cair Ayam Lokal dengan Berbagai Level MZEV secara In Vitro}

Motilitas spermatozoa ayam lokal pada berbagai level MZEV (Tabel 2) berbeda $(\mathrm{P}<0.05)$. Motilitas spermatozoa dengan suplementasi MZEV lebih baik dibandingkan tanpa minyak zaitun hingga 60 jam penyimpanan. Hal ini sesuai dengan hasil yang didapat Al-Daraji (2012) bahwa suplementasi minyak zaitun menghasilkan motilitas, viabilitas dan integritas akrosom spermatozoa lebih baik dibandingkan tanpa minyak zaitun selama 72 jam penyimpanan.

Selama 0 jam penyimpanan, suplementasi berbagai MZEV tidak menghasilkan perbedaan $(\mathrm{P}>0.05)$ namun 12 jam hingga 60 jam berikutnya menunjukkan perbedaan yang signifikan. Hal ini sejalan dengan penelitian Al-Daraji (2013) dengan penambahan level antioksidan bawang putih selama 0 jam tidak terlihat adanya perbedaan namun berbeda pada 24 hingga 48 jam.

Suplementasi $8 \%$ dan $10 \%$ MZEV pada 12 jam pertama menghasilkan motilitas terbaik namun pada jam ke-24, 36, 48 dan 60 level 8\% memberikan hasil yang lebih baik dari level $10 \%, 6 \%$ dan $4 \%$. Hal ini sedikit berbeda dengan hasil yang didapat oleh Al-Daraji (2012) bahwa motilitas spermatozoa ayam leghorn putih yang disuplementasi minyak zaitun tidak berbeda antara $4 \%$ dengan $8 \%$ selama 72 jam penyimpanan.

Hasil penelitian ini menunjukkan bahwa peningkatan level MZEV sejalan dengan peningkatan angka motilitas selama penyimpanan. Namun, suplementasi $10 \%$ MZEV menghasilkan motilitas spermatozoa yang lebih rendah dari 8\%. Hal ini mungkin disebabkan kadar MZEV terlalu tinggi sehingga pergerakan spermatozoa terhambat oleh banyaknya molekul-molekul lemak dari MZEV.

Viabilitas spermatozoa ayam silangan lokal berbeda $(\mathrm{P}<0.05)$ pada berbagai level MZEV (Tabel 3). Hasil ini dapat dilihat bahwa viabilitas spermatozoa dengan suplementasi MZEV lebih baik dibandingkan tanpa minyak zaitun hingga 60 jam penyimpanan. Hal ini sesuai dengan hasil yang didapat Al-Daraji (2012) bahwa suplementasi minyak zaitun menghasilkan viabilitas, viabilitas dan integritas akrosom spermatozoa lebih baik dibandingkan tanpa minyak zaitun selama 72 jam penyimpanan. Selama 0 jam penyimpanan, suplementasi berbagai MZEV tidak menghasilkan perbedaan $(\mathrm{P}>0.05)$ namun 12

Tabel 2. Persentase motilitas spermatozoa ayam lokal selama penyimpanan dengan suplementasi berbagai level minyak zaitu nekstra virgin (rerata \pm SEM)

\begin{tabular}{cccccc}
\hline \multirow{2}{*}{ WP } & \multicolumn{5}{c}{ Perlakuan } \\
\cline { 2 - 6 } & P0 & P1 & P2 & P3 & $82.50 \pm 1.15$ \\
\hline 0 & $82.50 \pm 1.15$ & $82.50 \pm 1.15$ & $82.50 \pm 1.15$ & $82.50 \pm 1.15$ & $67.92 \pm 2.42 \mathrm{~cd}$ \\
12 & $50.83 \pm 1.61 \mathrm{a}$ & $61.67 \pm 1.88 \mathrm{~b}$ & $65.00 \pm 1.07 \mathrm{bc}$ & $71.67 \pm 1.78 \mathrm{~d}$ & $58.75 \pm 2.05 \mathrm{c}$ \\
24 & $43.75 \pm 1.39 \mathrm{a}$ & $48.33 \pm 1.67 \mathrm{a}$ & $53.75 \pm 1.64 \mathrm{~b}$ & $64.58 \pm 1.44 \mathrm{~d}$ & $49.17 \pm 1.49 \mathrm{c}$ \\
36 & $32.50 \pm 1.57 \mathrm{a}$ & $38.33 \pm 1.42 \mathrm{~b}$ & $42.50 \pm 2.17 \mathrm{~b}$ & $57.08 \pm 1.68 \mathrm{~d}$ & $40.42 \pm 1.30 \mathrm{~d}$ \\
48 & $22.92 \pm 1.14 \mathrm{a}$ & $28.75 \pm 1.96 \mathrm{~b}$ & $34.17 \pm 1.49 \mathrm{c}$ & $48.33 \pm 1.28 \mathrm{e}$ & $29.58 \pm 1.44 \mathrm{~d}$ \\
60 & $14.58 \pm 0.96 \mathrm{a}$ & $18.75 \pm 1.25 \mathrm{~b}$ & $25.42 \pm 0.96 \mathrm{c}$ & $39.58 \pm 1.30 \mathrm{e}$ & 5 \\
\hline
\end{tabular}

Keterangan : Superskrip berbeda pada baris yang sama oleh huruf yang berbeda pada baris yang sama menunjukkan perbedaan yang nyata $(\mathrm{P}<0.05)$. WP = waktu penyimpanan. 
Tabel 3. Persentase viabilitas spermatozoa ayam lokal selama penyimpanan dengan suplementasi berbagai level minyak zaitun ekstra virgin (rerata \pm SEM)

\begin{tabular}{cccccc}
\hline \multirow{2}{*}{ WP } & \multicolumn{5}{c}{ Perlakuan } \\
\cline { 2 - 6 } & P0 & P1 & P2 & P3 & P4 \\
\hline 0 & $92.52 \pm 1.07$ & $92.52 \pm 1.07$ & $92.52 \pm 1.07$ & $92.52 \pm 1.07$ & $92.52 \pm 1.07$ \\
12 & $61.30 \pm 1.93 \mathrm{a}$ & $72.18 \pm 1.67 \mathrm{~b}$ & $74.32 \pm 1.01 \mathrm{bc}$ & $80.86 \pm 1.67 \mathrm{~d}$ & $77.84 \pm 2.23 \mathrm{~cd}$ \\
24 & $54.10 \pm 1.24 \mathrm{a}$ & $58.08 \pm 1.66 \mathrm{a}$ & $63.16 \pm 1.65 \mathrm{~b}$ & $75.08 \pm 1.50 \mathrm{~d}$ & $69.13 \pm 1.80 \mathrm{c}$ \\
36 & $41.80 \pm 1.56 \mathrm{a}$ & $48.68 \pm 1.57 \mathrm{~b}$ & $52.02 \pm 2.04 \mathrm{~b}$ & $66.54 \pm 1.57 \mathrm{~d}$ & $59.09 \pm 1.40 \mathrm{c}$ \\
48 & $32.33 \pm 1.25 \mathrm{a}$ & $39.02 \pm 1.87 \mathrm{~b}$ & $43.34 \pm 1.52 \mathrm{c}$ & $59.07 \pm 1.32 \mathrm{e}$ & $50.94 \pm 1.45 \mathrm{~d}$ \\
60 & $23.84 \pm 0.94 \mathrm{a}$ & $29.13 \pm 1.13 \mathrm{~b}$ & $36.04 \pm 1.22 \mathrm{c}$ & $49.82 \pm 1.21 \mathrm{e}$ & $39.61 \pm 1.59 \mathrm{~d}$ \\
\hline
\end{tabular}

Keterangan : Superskrip berbeda pada baris yang sama oleh huruf yang berbeda pada baris yang sama menunjukkan perbedaan yang nyata $(\mathrm{P}<0.05)$. WP $=$ waktu penyimpanan.

jam hingga 60 jam berikutnya menunjukkan perbedaan yang signifikan. Suplementasi $8 \%$ dan $10 \%$ MZEV pada 12 jam pertama menghasilkan viabilitas terbaik namun pada jam ke-24, 36, 48 dan 60, level 8\% memberikan hasil yang lebih baik dari level 10\%, 6\% dan 4\%. Hal ini sejalan dengan Al-Daraji (2012) yang menemukan bahwa viabilitas spermatozoa ayam leghorn putih yang disuplementasi minyak zaitun $8 \%$ lebih tinggi dari $6 \%$ dan 4\% selama 72 jam penyimpanan. Suplementasi $10 \%$ MZEV pada penelitian ini menghasilkan viabilitas spermatozoa yang lebih rendah dari $8 \%$. Penyimpanan semen ayam selama 60 jam dengan suplementasi minyak zaitun ekstra virgin pada penelitian ini menghasilkan motilitas spermatozoa hingga $18.75 \pm 1.25 \%$ dan viabilitas spermatozoaa hingga $29.13 \pm 1.13 \%$ sangat rendah dibandingkan hasil penelitian Al-Daraji (2012) yang mendapatkan motilitas dan viabilitas spermatozoa ayam leghorn putih dengan suplementasi minyak zaitun pada pengencer semen yang mengandung fruktosa berada pada kisaran 60\% selama 72 jam penyimpanan. Hal ini disebabkan karena AlDaraji (2012) menggunakan pengencer yang dilengkapi antioksidan lain selain minyak zaitun yaitu vitamin A, C dan $\mathrm{E}$ ke dalam pengencer semen sehingga motilitas dan viabilitasnya lebih tinggi dari penelitian ini. Kombinasi beberapa jenis antioksidan memberikan perlindungan yang lebih baik (sinergisme) terhadap oksidasi dibanding dengan satu jenis antioksidan saja (Pratt dan Hudson, 1990). Hasil ini dapat diartikan bahwa penambahan antioksidan MZEV efektif dalam mempertahankan motilitas spermatozoa ayam lokal selama penyimpanan. Penyimpanan semen selama 60 jam pada suhu $5{ }^{\circ} \mathrm{C}$ menyebabkan terjadinya cekaman dingin pada spermatozoa. Pursel (1979) menyatakan bahwa cekaman dingin dapat meningkatkan kerentanan spermatozoa terhadap peroksidasi lipid. Peroksidasi lipid dapat disebabkan adanya radikal bebas. Peroksidasi lipid yang berkepanjangan merusak struktur matrik lipid dan menyebabkan instabilitas pada membran (Feradis, 2010). Peroksidasi lipid menyebabkan beberapa kerusakan pada spermatozoa unggas, berupa kerusakan morfologis, penurunan motilitas, dan daya fertil (Long dan Kramer, 2003). Spermatozoa ayam yang terekspos dengan udara saat diejakulasikan dapat mengalami peroksidasi lipid yang dapat menurunkan motilitas dan viabilitasnya (Surai, 2003). Minyak zaitun mengandung senyawa antioksidan
fenolik.Senyawa fenolik polar mayor minyak zaitun terdiri dari 4 kelompok yaitu fenol sederhana (hydroxytyrosol, tyrosol), secoiridoids (oleuropein, aglikon ligstrosida, dan masing-masing derifat dialdehid dekarboksilasi), flavonoid (apigenin, luteolin) dan lignan $[(+)-1$ acetoxypinoresinol dan pinoresinol] (Kampa et al.,2009).Beberapa kandungan fenolik pada minyak zaitun, oleuropein memegang peranan yang cukup penting sebagai antioksidan pada spermatozoa ayam selama penyimpanan, hal ini disebabkan karena oleuropein bertindak sebagai pencegah terjadinya reaksi antara radikal bebas dengan asam lemak tak jenuh ganda pada membran sel spermatozoa ayam. Dari beberapa penelitian menunjukkan bahwa oleuropein bertindak sebagai pembersih (scavenger)radikal bebas dan menghambat produksi radikal bebas (Kruk et al., 2005), mengurangi level spesies oksigen reaktif karena efektif mengikat radikal hidroksil, superoksida dan peroksil secara in vitro (Rice-Evans, 2004) dan dapat mengurangi jumlah protein teroksidasi pada fibro blast embrio manusia (Katsiki et al., 2007). Senyawa penolik pada minyak zaitun dapat mengikat spesies oksigen reaktif pada sel darah putih (Paiva-Martin et al.,2009)

Komponen polifenol lain yang utama pada minyak zaitun adalah hydroxytyrosol (Hty) (Goya et al., 2007) dan hydroxytyrosyl acetate(Hty-A) (Pereira-Caro et al., 2012). Kandungan Hty dan Hty-A pada minyak zaitun yang digunakan pada penelitian turut membantu menghambat kerusakan spermatozoa dengan cara mencegah stres oksidatif pada spermatozoa ayam. Hal ini sesuai dengan pendapat Goya et al. (2007) dan Martin et al. (2010) bahwa Hty efektif mencegah sel dari stres oksidatif dengan cara mengikat radikal (radical scavenger) dan mengatur protein signal yang melibatkan induksi enzim krioprotektif, dengan demikian dapat berperan dalam mekanisme proteksi sel tambahan.Hty menjadi kemo-protektif terbaik karena mekanisme ganda yang dimilikinya dalam mencegah stres oksidatif yang dapat menyebabkan kerusakan sel, namun Hty-A lebih efisien dalam memelihara integritas membran biologis daripada Hty karena Hty-A memiliki akses ke dalam membran sel yang lebih baik. Kompoen alami Htydan HTy-A pada minyak zaitun efektif melindungi sel hepatik dari kerusakan oksidatif (Sarria et al.,2012). Antioksidan HT dan oleuropein lebih efektif sebagai pelindung dibandingkan BHT atau vitamin E (Visioli et al.,1998). Beberapa penelitian lain menunjukkan efek 
hepatoprotektif antioksidan penol di dalam minyak zaitun ekstra virgin dalam melawan stres oksidatif in vitro maupun in vivo (Deiana et al., 2007; Goya et al., 2007; Sarria et al.,2012) serta mempunyai efek perlindungan terhadap kerusakan DNA (Nousis et al., 2005; Machowetz et al.,2007; Fabiani et al., 2008).

\section{Kualitas Semen Cair Ayam Lokal dengan Level Minyak Zaitun Ekstra Zaitun 8\% secara In Vivo}

Pengencer RF + MZ 8\% pada semen ayam lokal menghasilkan fertilitas spermatozoa sebesar $73.81 \pm 12.67 \%$ dengan periode fertil $14.00 \pm 1.73$ hari. Fertilitas spermatozoa ayam kampung pada penelitian ini sebesar $73.81 \pm 12.67 \%$ lebih tinggi dari yang didapatkan Sutiyono et al. (2006) dengan menggunakan ringer glukosa yang hanya mendapatkan $56.67 \%$ pada ayam kampung. Fertilitas spermatozoa ayam kampung dengan menggunakan pengencer RF + MZ 8\% pada penelitian ini cukup baik dari penelitian sebelumnya yang menggunakan pengencer $\mathrm{NaCl}$ fisiologis $0.9 \%$ yang menghasilkan fertilitas spermatozoa sebesar $70 \%$ pada ayam kampung, 56\% sampai dengan $65.79 \%$ pada ayam buras dan $44.13-66.67 \%$ pada ayam pelung (Sastrodihardjo et al.,1995; Sutiyono et al., 2006; Ridwan dan Rusdin, 2008; Asmarawati et al.,2013). Fertilitas spermatozoa ayam kampung pada penelitian ini juga lebih baik dari yang menggunakan pengencer $\mathrm{NaCl}$ fisiologis $0.9 \%+$ kuning telur, menghasilkan fertilitas spermatozoa sebesar $70.83 \%$ pada ayam kampung dan 66\% pada ayam buras (Sastrodihardjo et al.,1995; Sutiyono et al.,2006), demikian juga dengan pengencer ringer glukosa yang menghasilkan fertilitas spermatozoa sebesar $56.67 \%$ pada ayam kampung dan $71.58 \%$ pada ayam buras (Sutiyono et al.,2006; Ridwan dan Rusdin, 2008). Adapun untuk pengencer ringer laktat menghasilkan fertilitas spermatozoa sebesar $74.73 \%$ pada ayam buras dan $56.18 \%$ pada ayam kate (Ridwan dan Rusdin, 2008; Saleh dan Isyanto, 2011) hampir sama dengan fertilitas spermatozoa ayam kampung dan sentul pada penelitian ini.

Fertilitas ayam lokal pada penelitian ini juga lebih baik dari pengencer natrium sitrat + kuning telur yang hanya mendapatkan 55\% pada ayam buras (Sastrodihardjo et al., 1995), namun lebih rendah dari fertilitas spermatozoa dengan pengencer natrium fosfat+ kuning telur yaitu $83 \%$ pada ayam buras (Sastrodihardjo et al., 1995).

Periode fertil yang didapatkan dari penelitian ini lebih tinggi dari yang didapatkan Solihati et al. (2006) yaitu 3.83-9.50 hari pada ayam buras. Periode fertil yang cukup lama ini mungkin disebabkan bahan pengencer yang digunakan pada penelitian ini cukup dapat mempertahankan daya hidup spermatozoa di dalam saluran kelamin betina karena adanya kandungan sumber energi yaitu fruktosa dan antioksidan minyak zaitun di dalam bahan pengencer tersebut.

Penggunaan pengencer RFMZ pada penelitian ini mampu mempertahankan periode fertil spermatozoa lebih lama dari penelitian sebelumnya yang menggunakan pengencer $\mathrm{NaCl}$ fisiologis $0.9 \%, \mathrm{NaCl}$ fisiologis $0.9 \%$ + kuning telur, natrium fosfat + kuning telur dan natrium sitrat + kuning telur yang masing-masing memperlihatkan periode fertil selama 6.33, 9.67, 12 dan 9.16 hari pada ayam buras (Sastrodihardjo et al.,1995). Namun hampir sama dengan yang didapatkan oleh Ridwan dan Rusdin (2008) yang menemukan periode fertil ayam buras dengan menggunakan pengencer $\mathrm{NaCl}$ fisiologis, ringer laktat dan ringer dekstrose berturut-turut 13.70, 15.30 dan 15.60 hari. Untuk satu kali IB (dengan kualitas semen yang baik dan berisi 100 juta spermatozoa), induk ayam akan terus menerus menghasilkan telur fertil selama 12 hari (Lake dan Stewart, 1978) atau 14 hari (Etches, 1996). Sarang spermatozoa (tubular gland) pada bagian anterior vagina betina merupakan tempat spermatozoa disimpan untuk sementara. Sekitar 75\% spermatozoa tersimpan dalam sarang sperma, namun hanya 4 sampai 20 spermatozoa yang berhasil menembus membran vitelin sel telur (Etches, 1996). Penyimpanan spermatozoaini menyebabkan spermatozoa dapat bertahan dari ancaman luar yang dapat merusak dan membunuh spermatozoa sehingga semakin lama spermatozoa di dalam tubular gland memungkinkan periode fertil semakin lama.

\section{KESIMPULAN}

Penggunaan minyak zaitun ekstra virgin mampu meningkatkan daya tahan spermatozoa selama penyimpanan 60 jam $\left(5^{\circ} \mathrm{C}\right)$. Level $8 \%$ minyak zaitun ekstrak virgin dapat digunakan sebagai antioksidan di dalam pengencer ringer fruktosa untukmempertahankan kualitas semen ayam lokal selama penyimpanan.

\section{DAFTAR PUSTAKA}

Al-Daraji, H.J. 2012.Adding olive oil to rooster semen diluents for improving semen quality and storage ability during liquid storage.Baltic Journal of Comparative and Clinical System Biology. 2: 3-11.

Al-Daraji, H.J. 2013. Effect of diluent supplementation with garlic extract on semen quality of cocks during liquid storage. Int. J. Pharm. Bio. Sci. 4(3): 1260-1270.

Al-Daraji, H.J. 2000. Effect of vitamin Eaddition to chicken semen on sperm quality during in vitro storage semen. Veterinary Research Forum. 2(2): 103-111.

Asmarawati, W., Kustono, D.T.Widayati, S.Bintara\&Ismaya. 2013. Pengaruhdosissperma yang diencerkan dengan $\mathrm{NaCl}$ fisiologis terhadap fertilitas telur pada inseminasi buatan ayam lokal. Buletin Peternakan. 37(1): 1-5.

Blesbois, E., M.Lessire, J. Grasseau, J.M.Hallouis\& D.Hermier. 1997. Effect of dietary fat on the fatty acid composition and fertilizing ability of fowl semen. Biol.Reprod.56(5): 1216-1220.

Cerolini, S., L. Zainiboni, A. Maldjian \& T. Gliozzi. 2006. Effect of docosahexaenoicacid and $\alpha$-tocopherol enrichment in chicken sperm on semenquality, sperm lipid composition and susceptibility to peroxidation. Theriogenology. 66: 877-886.

Deiana, M., A. Rosa, G. Corona, A. Atzeri, A. Incani \& F. Visioli. 2007. Protective effect of olive oil minor polar components against oxidative damage in rats treatedwith ferric-nitrilotriacetate. Food Chem. Toxicol. 45: 2434-2440.

Etches, RJ. 1996. Reproduction in Poultry. CABI, Wallingford. 
Fabiani, R., P. Rosignoli, A. de Bartolomeo, R. Fuccelli, M. Servili, G.F. Montedoro \&G. Morozzi. 2008. Oxidative DNA damage is prevented by extracts of olive oil,hydroxytyrosol, and other olive phenolic compounds in human bloodmononuclear cells and HL60 cells. J. Nutr. 138: 1411-1416.

Feradis. 2010. Bioteknologi Reproduksi pada Ternak. Alfabeta, Bandung.

Kampa, M., V. Pelekanou, G. Notas \& E. Castanas. 2009. Olive oil phenols, basic cell mechanism and cancer. In: Boskou D (Eds). Olive Oil: Minor Constituents and Health. CRC Press.

Katsiki, M., N. Chondrogianni, I. Chinou, A.J. Rivett \& E.S. Gonos. 2007. The olive constituent oleuropeinexhibits proteasome stimulatory properties in vitro and confers life span extension of human embryonic fibroblasts.Rejuvenation Res.10: 157-172.

Kruk, I., H.Y.Aboul-Enein, T.Michalska, K.Lichszteld\& A.Kladna. 2005. Scavenging of reactive oxygenspecies by the plant phenols genistein and oleuropein.Luminescence.20: 81-89.

Lake, P.E.\&J.M. Stewart. 1978. Artificial Insemination in Poultry.Her Majesty's Stationery Office, London.

Long, J.A. \& M. Kramer. 2003. Effect of vitamin E on lipid peroxidation andfertility after artificial insemination with liquid-stored turkey semen.Poult. Sci. 82: 1802-1807.

Machowetz, A., H.E. Poulsen, S. Gruendel, A. Wiemann, M. Fito, J. Marrugat, R. Torre, J.T. Salonen, K. Nyyssonen, J. Mursu J. 2007. Effect of olive oils on biomarkers of oxidative DNA stress in Northern andSouthern Europeans. F.A.S.E.B.J. 21 (1): 45-52.

Martin, M.A., S. Ramos \& A.B. Granado-Serrano. 2010. Hydroxytyrosol induces antioxidant/detoxificant enzymes activity and Nrf2 translocation via ERKs andPI3K/AKT pathways in HepG2 cells.Mol. Nutr. Food. Res. 54: 956-966.

Nousis, L., P.T. Doulias, N. Aligiannis, D. Bazios, A. Agalias, D. Galaris \& S. Mitakou. 2005. DNA protecting and genotoxic effects of olive oil related components incells exposed to hydrogen peroxide. Free Radic. Res. 39: 787-795.

Paiva-Martins, F., J. Fernandes \& S. Rocha. 2009. Effects of olive oil polyphenolson erythrocyte oxidative damage. Mol. Nutr. Food Res. 53: 609-616.

Partyka, A., E. Lukaszewicz \& W. Niżański.2012b. Lipid peroxidation and antioxidant enzymes activity in avian semen.Anim.Reprod. Sci. 134:184-190

Pereira-Caro, G., R. Mateos \& B. Sarria. 2012. Hydroxytyrosyl acetatecontributes to the protective effects against oxidative stress of virgin olive oil.Food Chem. 131: 869-878.

Pratt, D.E. \& B.J.F. Hudson. 1990. Natural antioxidant not exploited comercially. In: Food Antioxidants. Elseveir A Science, London.

Pursel, V.G. 1979. Effect of cold shock on boar sperm treated with butilated hydroxitoluene. Biol. Reprod. 21: 319-325.

Rice-Evans, C. 2004. Flavonoids and isoflavones: absorption, metabolism and bioactivity. Free Radic. Biol. Med. 36: 827-828.
Ridwan\& Rusdin. 2008. Konservasi semen ayam buras menggunakan berbagai pengencer terhadap fertilitas dan periode fertil spermatozoa pasca inseminasi buatan. J. Agroland. 15(1): 63-67.

Saleh, D.M. \& A.Y. Isyanto. 2011. Pengaruh lama penyimpanan terhadap motilitas dan fertilitas spermatozoa ayam kate lokal. Cakrawala Galuh. 1(6): 1-6.

Sarria, B., R. Mateos, E. Gallardo, S. Ramos, M.A. Martin \& L. Bravo. 2012. Nitroderivatives of olive oil phenols protect HepG2 cells against oxidative stress.Food Chem.Toxicol. 50: 3752-3758.

Sastrodihardjo, S., S. Mihardja, K. Heruwatno \& N. Hilmia. 1995. Pengaruh macam pengencer dan dosis inseminasi buatan terhadap periode fertil spermatozoa, daya fertilitas dan daya tetas telur ayam buras. Prosiding seminar hasil penelitian dan pengembangan bioteknologi II. Puslitbang bioteknologi LIPI, Bogor. Hlm 242-249.

Solihati, N., R. Idi, R. Setiawan, I.Y. Asmara\& B.I. Sujana. 2006. Pengaruh lama penyimpanan semen cair ayam buras pada suhu $5{ }^{\circ} \mathrm{C}$ terhadap periode fertil dan fertilitas sperma. J.I.T.V. 6 (1): 7-11.

Steel, R.G.D. \& J.H. Torrie. 1994. Principles and Procedures of Statistic. Mc Graw-Hill Int Book Com, London.

Suharyati, S. 2006. Pengaruh penambahan vitamin E dan mineral $\mathrm{Zn}$ terhadap kualitas semen serta fertilitas dan daya tetas telur kalkun lokal. J. Indon. Trop. Anim. Agric. 31(3): 179-183

Surai, P.F., N.Fujihara, B.K. Speake, J.P.Brillard, G.J.Wishart\& N.H.C. Sparks. 2001. Polyusaturated fatty acids, lipid peroxidation and antioxidant protection in avian semen. Asian-Aust. J.Anim. Sci. 14 (7): 1024-1050.

Surai, P.F. 2003. Natural Antioxidant in Avian Nutrition and Reproduction. Nottingham University Press, Nottingham.

Sutiyono, S. Riyadi\&S. Kismiati. 2006. Fertilitas dan daya tetas telur dari ayam petelur hasil inseminasi buatan menggunakan semen ayam kampung yang diencerkan dengan bahan berbeda. J.Indonesian Trop.Anim.Agric .31 (1): 36-40.

Visioli, F., G. Bellomo \& C. Galli. 1998. Free radical-scavenging properties of olive oil polyphenols. Biochem. Biophys. Res. Commun.247: 60-64.

Vissers, M.N., P.L.Zock\& M.P.Katan. 2004. Bioavailability and antioxidant effects of olive oil phenols in humans: a review. Eu. J.Clin.Nut. 58:955-965.

Vossen, P. 2007. Olive oil: history, production, and characteristic of the world's classic oils. Hortscience. 42(5): 1093-1100. 